\title{
Teachers' Experience in Curriculum Implementation: An Investigation on English Language Teaching in Vocational Colleges in Malaysia
}

\author{
Sanitah Mohd. Yusof*, Dalila Syazana Zainuddin, Abdul Rahim Hamdan \\ Fakulti Pendidikan, Universiti Teknologi Malaysia, 81310 UTM Johor Bahru, Johor, Malaysia
}

*Corresponding author: p-sanitah@utm.my

\begin{abstract}
This qualitative research aimed to explore teachers' experience in the implementation of the new English language curriculum in Malaysian vocational colleges. The research's focus is on English as a Second Language (ESL) teachers' perceptions on the new English language curriculum and its implementation, ESL teachers' strategies in implementing the new English language curriculum, and the problems and challenges that they face in implementing the new English language curriculum. A full qualitative research paradigm was employed using a phenomenology design, where 6 ESL teachers from Negeri Sembilan participated to share their insights on the research topic. The research used purposive sampling method, and the participants were selected based on research location. The research instrument used to collect the data was a semi-structured interview administered via Facebook video call and recorded with Callnote application software. This approach was chosen for its feasibility and cost-saving nature. Research findings show that ESL teachers are receptive of the curriculum change and most of them understand the new curriculum well. They have positive feelings towards it despite acknowledging negative curriculum aspects, having curriculum concerns and dealing with problems and challenges. Teachers recommended for proper training and support in order to improve the teaching and learning process in ESL classroom. The implications of the research findings have been outlined and highlighted, followed by several suggestions for the stakeholders involved, including ESL teachers, policymakers, training division, and vocational college administrators.
\end{abstract}

Keywords: ESL teacher, English Language curriculum, curriculum implementation, Malaysian vocational college.

(C) 2017 Penerbit UTM Press. All rights reserved

\subsection{INTRODUCTION}

Curriculum implementation is a multi-level process. In fact, a number of stakeholders are responsible to the success of a curriculum change. Ornstein and Hunkins (2009) include students, teachers, administrators, consultants, state employees, university professors, parents, lay citizens, and political officials as key players in curriculum implementation. Undeniable, each group of stakeholders holds different position in curriculum implementation, but these groups of people work together in playing their respective roles in promoting the change and ensuring the success of the curriculum implementation. However, a teacher brings a lot more to it, as he is the instigator of change in the classroom. He has the decision-making power over what is learnt and how it is learnt within the confine of his classroom setting. As proposed by Taba (1962), the teacher is an agent of change. Without his understanding of it, his awareness of its importance, and his willingness to implement a new intended curriculum, the new curriculum will remain just another idea in the field. It is in the hands of teachers that intended curriculum develops into an enacted curriculum.

The Technical and Vocational Education Division (BPTV) of Malaysia has undergone an educational transformation in the year 2013, whereby all vocational schools were upgraded into vocational colleges. With this change, the new curriculum of vocational colleges was adopted nationwide. Among the changes is the teaching of English Language. Students no longer study General English (GE) only and sit for 1119 papers in SPM, but they are taking both GE and English for Specific Purposes (ESP) modules. Hence, teachers face a new scenario, which is teaching ESP. In addition to that, instead of five period of 40-minute lesson weekly, they are now only left with a period a week, where contact hour is reduced to 1 hour. In fact, evaluation is conducted every semester, weighted 70-30 where 70 percent is graded through standardised final examination and 30 percent through ongoing college-based assessment. This curriculum change is a phenomenon that all English Language teachers have to deal with in vocational colleges throughout the nation. Their perception on the curriculum change influences their practice in the classroom, hence ensuring its success or failure.

\subsection{LITERATURE REVIEW}

Despite the growing interest in the newly established vocational colleges in Malaysia and its future contribution to Malaysian industries, as well as the nation's socioeconomic growth, a review of related literature shows that most studies are more concerned over the implementation of the vocational part of the curriculum reform (Azmanirah, Nurfirdawati, Marina, \& Jamil, 2014; Noorazman, Hairuddin, Wan Mohd Rashid, Noor Hisham \& Jamil, 2013). Little has been done on academic subjects and soft skill modules. In addition to that, no researcher has yet to seriously examine the sync between the new English Language curriculum for vocational colleges and its actual implementation. 
Most studies are more interested in issues such as the effectiveness of specific teaching approaches, methods, or strategies (Sirhajwan Idek, Lee, Sidhu, \& Teoh, 2014). Studies on teacher experience in dealing with this curriculum change are even more limited.

The present research is designed to fill this gap, by investigating English Language teachers' experience in curriculum implementation in the context of the Malaysian vocational colleges. Hence, this research will look at teachers' perceptions on the new English Language curriculum and its implementation, as well as their implementation strategies and challenges. Moreover, since the vocational college system is a fairly new curriculum in Malaysia, there is a need to ascertain its implementation in order to ensure its success. The findings of this research will be able to contribute in the effort to improve on the development of human capital. Are we on the right track in producing quality human capital? Are the standards depicted in the intended curriculum on par with the standards produced through the enacted curriculum? Is the intended curriculum being implemented the way it was desired? What are the challenges that are hindering success from the implementation? Teachers' perception is one of the factors affecting their willingness, participation and cooperation in curriculum implementation. It influences their acceptance or rejection of the new curriculum. Some teachers may receive it positively with openness and anticipation, while some may receive it negatively with hostility or indifference. Teachers' perceptions, attitudes and beliefs about the curriculum reform play a crucial role in the adoption, reinvention or rejection of a new curriculum (Carless, 1997; Kyriakides, 1997; Mulat, 2003). Hence, studies on teachers' perceptions are able to determine the success or failure of the curriculum.

Hypothetically, teachers with positive perceptions are more likely to anticipate the curriculum change and accept it openly. Positive perceptions will result in positive attitudes and behaviours that may be reflected in their teaching practices in the classrooms. Teachers who show positive attitudes and behaviour towards teaching and the innovation, will eventually brings positive outcome. Carless (1998) concluded that teachers with positive attitudes towards the innovation in the curriculum were able to find a way to foster it compatibly with the constructivist view of learning adopted. Webb (2010) found a remarkable upsurge in the use of 'interactive whole-class teaching' where confident teachers incorporated some aspects of best practice into their teaching. When teachers agree with the curriculum, they will implement it well. In contrast, teachers with negative perceptions are less likely to be eager in accepting a new curriculum. Most often than not, the reason being is the fact that the curriculum does not favour them, especially when it is beyond teachers' capabilities. Harvey (1990) listed lack of ownership, lack of benefits, increased burdens, lack of administrative support, loneliness, insecurity, norm incongruence, boredom, chaos, differential knowledge, sudden wholesale change, and unique points of resistance as the reasons why people resist change. O'Sullivan (2002) reported that there was no evidence of teachers using learner-centered and communicative approaches as suggested in the reform strategies. Likewise, Wang (2008) found that teachers continue to adopt teacher-centered approach when asked to change to a studentcentered communicative approach. When teachers disagree with the curriculum, it will cause unexpected implementation and resistance to change.

The overall purpose of this research is to explore teachers' experience in the implementation of the new English Language curriculum in Malaysian vocational colleges. In investigating ESL teachers' perceptions on the new English Language curriculum and its implementation, this research will be uncovering the factors that are affecting teachers' implementation. Through the exploration of ESL teachers' strategies in implementing the new English Language curriculum, this research will be looking at the teaching practices employed by the teachers in the classroom. The identification of challenges that ESL teachers face in implementing the new English Language curriculum will be able to elicit the difficulties and problems that teachers experience in the implementation process. With the findings on factors, teaching practices, and challenges in regards to the curriculum implementation, this research aims to help policymakers in gaining a better understanding of the impact of the curriculum on the teaching and learning of ESL. It is also aimed to contribute in the development of curriculum planning and innovation, especially in the teaching and learning of ESL in vocational colleges.

\subsection{METHODOLOGY}

In order to attain information on teachers' experience in the implementation of the new English Language curriculum in Malaysian vocational colleges, a full qualitative research paradigm was employed. Creswell (2007) states that qualitative research is conducted when there is a need for a complex, detailed understanding of the issue. Hancock, Ockleford, and Windridge (2009) suggest that qualitative research is concerned with developing explanations of social phenomena to understand the social world in which we live.

\section{Research Design}

For this research, a phenomenology design was selected to gain information regarding teachers' experience in curriculum implementation. Smith, Flower, and Larkin $(2009$, p. 11) describe phenomenology as "a philosophical approach to the study of experience . . . [that] shares a particular interest in thinking about what the experience of being human is like, in all of its various aspects, but especially in terms of the things that matter to us, and which constitute our lived world."

The research exercised the purposive sampling method in choosing its participants. The choosing of this method is influenced by access and willingness concerns (Creswell, 2007). One group of participants is involved in this research; six English Language teachers in Malaysian vocational colleges located in Negeri Sembilan. All the English Language teachers who are teaching in Malaysian vocational colleges in Negeri Sembilan are suitable to participate in the research. This is so since all of them are teaching GE and ESP modules. In fact these teachers are similar in two other aspects; 1) they have minimum qualification of a degree in TESL, English studies, or Linguistics, and 2) they have a minimum of two years of teaching experience in the new curriculum.

The data collection method that was administered to collect valuable data from the participants, was semi-structured interview sessions that were administered online via Facebook video call and recorded via Callnote software application. The researcher opted to utilise the use of technology in this research for its feasibility and economical nature. The interview protocol used to collect the data was adapted from Nor Haslynda A. Rahman's protocol (2014) in her research entitled "From curriculum reform to classroom practice: An evaluation of the English primary curriculum in Malaysia." Originally there were 7 sections that contained 33 questions, but for the purpose of this research, only 6 sections are being used, in which 19 questions have been selected to help gather the data needed. 


\section{Data Analysis}

Data obtained from the interview transcripts was organised manually using thematic analysis. Moustakas (1994) illustrated the transcendental phenomenology procedures which include 1) the identification of a phenomenon to study, 2) bracketing out of one's experiences, 3) the collection of data from several persons who have experienced the phenomenon, 4) reducing the information to significant statements or quotes, 5) combining the statements into themes, 6) the development of textural description of the experiences (what participants experienced), 7) the development of structural description of their experiences (how they experienced it in terms of the conditions, situations, or context), and 8) the development of a combination of the textural and structural descriptions. Steps 4 to 8 are the data analysis steps that were used to decipher the essence of teachers' experience. To assist the researcher in completing these steps, the researcher has chosen to include several phases of qualitative data analysis from Berg (2004); namely data organisation, becoming familiar with the data, coding, and data category.

Before reducing the information to significant statements or quotes (Step 4), the data was first transcribed into written form. The transcription process was conducted manually by listening to each recording on Callnote library for 5-10 times to ensure the accuracy and the clarity of the data transcription. While listening, the researcher copied word by word, including signals such as mm..., yaa..., err..., and okay as shown in Table 1 below. In fact, gestures such as laughter, eye movement, and facial expression were noted to get accurate message conveyed by the respondents. After the transcription process of the 6 data recordings, the researcher read the transcribed data in order to identify spelling and punctuation errors before sending them to the respondents via email for verification purposes.

Table 1 Example of transcription

I: How about the positive and negative aspects?

R2: Mm.. Well.. I think.. Simple and easy so students won't feel burdened by it. Practical as students see its relevance and usefulness. Focused on learning the language in order to communicate. But it's superficial.. it does not develop their thinking skills. And it's still restricted.. it does not encourage creativity, as there are still formats and patterns. Er.. I think that's it.

Upon receiving verification from the respondents, the researcher began with Step 4 by organising the data to reduce the information transcribed. Each of the transcription was classified based on the respondents' identity; R1, R2, R3, R4, R5, and R6. Every sentence of the transcription text was separated and boxed in the form of tables. Unhelpful statements were removed from the tables, and significant statements and quotes remained to help the researcher in finding answers to the research questions. However, raw data was saved in a separate folder to prevent data loss.

The researcher spent some time reading and rereading the sentences in order to become familiar with the data. The table was then modified to include the sub-items of the research questions as the headings of each group of sentences, as illustrated in the following example in Table 2.

Table 2 Example of data organization

\begin{tabular}{|l}
\hline $\mathbf{R 3}$ \\
\hline Statement \\
\hline Positive and Negative Aspects of Curriculum \\
\hline Simple and easy so students won't feel burdened by it. \\
\hline Practical as students see its relevance and usefulness. \\
\hline Focused on learning the language in order to communicate. \\
\hline But it's superficial; it does not develop their thinking skills. \\
\hline And it's still restricted; it does not encourage creativity, as there are still formats and patterns. \\
\hline
\end{tabular}

Next, the researcher moved on to coding and categorising the data in order to combine the statements into themes (Step 5). Coding is the process of naming the category and data segments with abbreviations (known as codes), which directly formulate the specific meaning of each data that formed the theory (Strauss \& Cobin, 1998). The codes derived from the coding process helped the researcher in forming themes, as codes made it easier for the formation of categories and subcategories. The category of data was obtained when similar phrases are found repeatedly in the data. Table 3 below shows an example of building categories, sub-categories and themes.

Table 3 Example of building categories, sub-categories, and themes

\begin{tabular}{|l|l|l|}
\hline Research Question & Category and Sub-category & Theme \\
\hline $\begin{array}{l}\text { What are the challenges } \\
\text { that they face in } \\
\text { implementing the new } \\
\begin{array}{l}\text { English Language } \\
\text { curriculum? (C) }\end{array}\end{array}$ & $\begin{array}{l}\text { *Student Attitude (SA) } \\
\text { *Time Constraint (TA) } \\
\text { *Adaptation (A) } \\
\text { *Limited Exposure (LE) } \\
\text { *Extra Effort (EE) } \\
\text { *Teacher Burden (TB) } \\
\text { *Student Progress (SP) } \\
\text { *Evaluation (E) }\end{array}$ \\
\hline
\end{tabular}


Then, the themes frequency table (see Table 4) was formed to show the most important theme for each issue investigated.

Table 4 Example of frequency of themes

\begin{tabular}{|l|c|c|c|c|c|c|}
\hline Impact on Teachers' Teaching & R1 & R2 & R3 & R4 & R5 & R6 \\
\hline Autonomy & & & & & & \\
\hline Easy & & & & & & \\
\hline
\end{tabular}

Respondents' experience was then elaborated in the discussions from two perspectives. Teachers' experience was not only discussed on the surface; what they experienced, but also at a deeper level; how they experienced it. These two perspectives helped the researcher to make connections between what was experienced and how it was experienced to truly describe the phenomenon.

\subsection{RESULTS AND DISCUSSION}

\section{ESL Teachers' Perceptions}

The findings presented show that teachers have a mixture of conceptions on the new curriculum. They are mainly receptive, however they seem to be unconvinced and unsatisfied in a few areas of the curriculum implementation. Below is a detailed discussion on ESL teachers' perceptions on the new English language curriculum and its implementation in Malaysian vocational college.

\section{Impact on Teacher's Teaching and Students' Learning}

Teachers find that the impact of the new curriculum towards their teaching practice is the autonomy that it presents. With the new curriculum, they now can decide on the content of the curriculum, either collectively in the English language panel, or individually on their own. The power is now in their hands. Teachers select content that are relevant to the students, both for personal use and vocational purposes. They also consider students' needs and interests in the selection of materials to develop the teaching and learning modules. Teachers also feel that the new curriculum helps them in making teaching an easier process. The use of locallydeveloped modules has provided teachers with a feeling of ownership on their teaching practice. The relationship between classroom autonomy and the use of textbooks has long been discussed, as Wang and Han (2002) connect the little autonomy of EFL teachers in the classroom and the dependency on textbooks use.

"Yes, this is because the teachers have the autonomy in developing modules that they see fit." (I-T-A-R2)

"In terms of preparation, it makes my teaching life easier because during school holidays, I'll be spending time to prepare what we're going to teach, so when the term reopens, you are well prepared." (I-T-E-R1)

As for the curriculum's impact on students' learning, teachers associate it to teachers' autonomy in making decisions on the curriculum content. Teachers view the impact as positive, identifying relevant content, preparation for vocational purposes, language mastery, independent learning, and focused teaching as impacts on students' learning. In fact, with the introduction of modules in the classroom, learner autonomy takes place due to the nature of the tasks that require students to be active an independent. Scharle and Szabó (2000) assert that language learning can only happen when there is a willingness to contribute from the students' side. Hence, the development of responsibility and autonomy is important in ESL classroom.

"In addition, the simplified syllabus focuses on developing students' actual application of English and not to merely prepare them for exams, the new curriculum is intended to train and prepare students for the real world and job market, it is an initial step of developing ESP, English for Specific Purpose." (I-L-M-R2, I-L-VP-R2)

However, there is also a worry on the negative impacts since they view the new curriculum as a simplified and reduced version of the previous curriculum. If that is so, it is the teachers' role to make learning variety by supplementing language lessons with more activities and materials.

"As for my students' learning, they learn less than what other students in normal schools learn, so come examination, students tend to fail." (I-L-LL-R5, I-L-FL-R5)

\section{Understanding of Curriculum}

In general, it seems that teachers have come to an understanding of the curriculum. After all, it has been four years since the curriculum transformation took place. Through experiences, they have developed a better understanding in comparison to their first year experiencing the new curriculum.

Teachers believe that the curriculum is practical and convenient in promoting independent learning among students in teachers' attempt to develop students' communicative ability. In developing students' fluency, language skills are used for 
vocational purposes in order to prepare them for their future vocations. This is parallel to the objectives of educational transformation in the vocational education field. Students need to be made aware of the importance of English language, for today use and also the future. Hiew (2012) reports on passive learners who view English as a language that has no necessity and practicality in their future, and the research findings show that it is recommended that teachers should make learning worthwhile and practical for the students.

"As for characteristics, it's meant to be practical, convenient and communicative, students need to learn the language in easier manner and learn to use it in real way especially when it is used to communicate." (U-C-P-R2, U-C-CV-R2, U-C-C-R2)

In addition to the curriculum's practicality, teachers are able to compare and contrast between the new curriculum and the previous one. Despite the differences like time allocation, curriculum content and materials, and assessment methods, teachers feel that the new curriculum does not differ much from the previous once since it still has an indirect focus on the standardised examination.

"The difference lies in the assessment methods, as the new curriculum involves ongoing assessments, on top of standardised examination." (U-D-A-R6)

Hence, it seems superficial that the goals are set on language skills, yet at the end of the day, students' grades mean much more to both students and teachers. Teachers should avoid this by any means as exam-oriented education has more negative influences on language learning. Kirkpatrick and Zang (2011) found that focusing too much on examination can results in stifling students' imagination, creativity, and sense of sense.

It is also worthy to note that teachers pinpoint to more positive aspects of the curriculum, than the negative ones. It gives away the idea that that teachers perceive the curriculum positively in general. They like the autonomy the curriculum allows them, its practicality and feasibility, as well as its potential in developing students who are communicative competent. However, teachers find that the time allocation is the biggest hindrance to objectives attainment. They view it as absurd and wish for more contact hours with the students. One contact hour per week is too little for any language learning.

"Problem is, the time allocation is ridiculous; one contact hour per week is not enough." (U-N-TA-R1)

"Negative aspects are: the short time of face to face lesson, and students don't have enough time to revise on English grammar and sentence structures with their teachers." (U-N-TA-R3)

Nunan (2011) argues that intensive, lengthy, infrequent lessons is a traditional instruction, so he recommends for language delivery in relatively small chunks over an extended period of time because it is more effective to do so. Perhaps, a few $40-45$ minute period chunks used in the previous curriculum would sound more pleasing to ESL teachers in vocational colleges.

The same issue is brought up again when teachers discuss the practicality and appropriateness of the curriculum. Teachers also describe the benefits that may come with the new curriculum, including its relevancy and its ability to achieve the curriculum goals. Though teachers find the curriculum as practical, appropriate and beneficial, it is worth to question, 'How can teachers ensure that since they barely have time with the students?' That answer must lie in the strategies that they adopt in their teaching practice.

\section{Perception on Training}

In general, there was no proper training that took place to prepare the teachers for the curriculum transformation. For the purpose of disseminating information, briefings and meetings were conducted at various levels. So, teachers' involvement in the 'training' varies greatly. Some were fortunate to be selected to represent their college at zone-meeting, but some did not even have the opportunity to go through a proper in-house training. Teacher training is important in order to ensure that teaching practices in the classroom do not derail from the vocational college's objectives.

"The training is important to help the educators to understand the underlying concept of the new curriculum." (T-N-S-R4)

"But I think it was necessary as the first step to deal with the curriculum change." (T-N-S-R6)

In fact, Schramm-Possinger (2012) illustrates the strong and positive relationship between well-executed teacher training and high-level student learning, citing countries like Finland, Sweden, Singapore, Hong Kong and Korea as evidences. Malaysia and its education system would benefit more if the same amount of attention given to technology were given to teacher training. The current trend in Malaysia right now is costly high-tech transformation that does not include training teachers for its implementation. 
Nonetheless, teachers make full use of any opportunity that comes their way and opt for the creation of a sharing platform, a support group, or a think-tank. Though they find the training provided as insufficient, teachers say that they are at the very least informative and that is considered necessary as the first step to curriculum implementation. As a result of the barely-there training that they experienced, teachers naturally develop a wishful thinking attitude, hoping for improvement, perhaps in the future. They wish to be included in the curriculum development, and they recommend for a more interactive, hands-on and periodical training.

\section{Perception on Curriculum Materials and Modules}

The materials and modules used in this new curriculum is not standardised due to college-based development. Hence, each college's strategy in developing them varies greatly. However, teachers used the same curriculum standard document for vocational college as the basis of development. Therefore, content and evaluation methods might not differ much. Discussed below is teachers' perception on the curriculum materials and modules.

Teachers generally find the materials as ineffective and unsuitable, despite the autonomy that they have to personally pick relevant content. Why? The pressing matter once again reappears; time constraint in the classroom. Teachers note that the vocational students need a lot of help in their English, for an example a basic technical part like grammar, which is impossible to be taught on top of everything else, in a span of an hour a week. Hence, teachers conclude that fluency is achievable, but not accuracy. In addition to that, teachers note that the simplification of the curriculum does not do justice to the curriculum. It makes the curriculum superficial and repetitive.

"The change was sudden, and due to lack of time, the module preparation was horrible; some materials were outdated, contained errors, and messy; I was frustrated by the work of the other panel members but I was the youngest, so there was not much I could do about it." (M-N-US-R6)

However, teachers like the idea of a modular approach and prefer the use of modules in classroom. They like it as a guideline for both teachers and students, and the fact that the modules allow the teaching and learning process to be flexible. The modules are a lot more fun and interesting in comparison to textbooks, but one teacher feels that textbooks contain useful exercises. Perhaps, modules and textbooks can be used hand in hand.

To conclude, teachers still have their concerns in using the modules. They worry about objective achievement, the development of the modules, and their classroom control. They also say that the autonomy, time constraint (yet again) and student attitude affect the use of the modules.

"Sometimes, when letting my students to work with the tasks given on their own, I'm afraid that I might lose control of the class." (M-C-C -R3)

"My concern is that the students don't really take this seriously." (M-C-SA-R1)

\section{ESL Teachers' Strategies in Implementation}

As aforementioned before, there is a lack of training for the teachers. Thus, teachers cope with the curriculum transformation by being creative and resourceful. The aim is to be able to carry out the responsibility that has been handed to them.

\section{Personal Development Attempts}

Teachers opt for personal development attempts to complement the training. Their effort in being resourceful include taking online courses that are related to their teaching life, conducting their own personal research on the Internet, investing in technology like e-books, software and mobile applications for classroom use. In fact, teachers also use their connection to create their own support group, by seeking help from peers, and creating a think-tank for sharing ideas. They also take the effort to collaborate with other higher education institutions like established polytechnics and universities for benchmarking and sharing sessions. Research has proven that social, material, and financial support are requisite to the success of curriculum implementation (Fullan \& Miles, 1992; Li, 1998; Carless, 1999). Hence, ESL teachers in vocational colleges' strategies in attempting personal development are on the right track to support curriculum implementation.

"I invest in e-books, software, and mobile applications that I can use to either help me with lesson creation or help me in being resourceful." (T-PD-R -R6)

"Definitely, we had some benchmarking sessions at some polytechnics and universities." (T-PD-C -R1)

\section{Curriculum Materials and Modules}

The roles of the curriculum materials and modules help in enhancing active learning and student-centred approach. Teachers say that the modules encourage participation because of their ability to create open and supportive environment. Basically, most of the tasks require students' independent learning. However, that depends on the content too. Students are picky, in the sense that they will mostly feel interested to participate when the content are relevant to them. In using the modules, teachers are being quite 
flexible. They add supplementary materials and activities to complement the modules developed. Most teachers use them as a guide or a base to lesson planning, bringing in additional materials and activities. A response elicited confirms that teachers go beyond the one-hour contact hour in order to ensure students' development. This includes extra classes and consultation hours outside classroom time.

"The module does help me to realise that the students have interest and potential to speak in English, provided that we give them the comfortable and supportive environment." (M$\mathrm{R}-\mathrm{P}-\mathrm{R} 2)$

"Whenever it is necessary I will make changes by using my own activities and materials, or else I just use the suggested activities in the modules when I think my students are able to complete it." (M-S-SS -R4)

\title{
Teachers' Role
}

Teachers are clear about their roles in the implementation process of the new curriculum. They view themselves mainly as a facilitator in the classroom that assists students' learning. However, they also play other roles; developer, trainer, evaluator, collaborator, researcher, and observer. They believe that they are playing the roles that they are expected to. They are also confident that they have done their best. Nonetheless, they are open for improvement. Some teachers also think that they are only half-way there in fulfilling their roles in the curriculum implementation, but they are confident that they will get there. As stressed by Dudley-Evans and St. John (1998), an ESP practitioner embodies multiple roles; teacher, researcher, evaluator, course designer, and collaborator. He is expected to execute research and collaborate with specialists in order to design the course, teach the course, and evaluate learners' achievement. Phani Kiran (2013) proposed the addition of two more roles of an ESP practitioner, which are learner and facilitator. He states that teachers are actively learning when they are fulfilling the functions of a teacher. He also suggests that as a facilitator, a teacher provides circumstances for students to engage with learning opportunities. These roles are no simple tasks and require a lot of time and effort from ESP teachers in order to ensure quality and effective teaching.

\begin{abstract}
"As a facilitator; the new curriculum gives more chance to students to solve and handle any tasks given on their own; it is more learner-centred compared to the former curriculum." (TR-F-R3)

"I see myself as a facilitator and a trainer, I assist their development, I demonstrate them the skills and I supervise their progress, but I am not drilling them into memorising things for exams or impose rules for them to practise which I did with the old curriculum." (TR$\mathrm{F}-\mathrm{R} 2$, TR-T -R2)
\end{abstract}

\section{Challenges that Teachers Face in Implementation}

It is only natural that teachers face challenges and obstacles in implementing the new curriculum. The discussion of the problems that they face in using the modules, the significant problems in their everyday teaching, and the challenging aspects of the curriculum implementation is as follows;

\section{Problems in Using the Modules}

Teachers identify the problems in using modules to be either student-related, or module-related. The modules developed are unsuitable for a majority of the students. They can either be too difficult or too easy for the students, and this problem exists due to student variety in a class. Plus, students do not take the modules seriously as most of the assessments are not awarded from the module completion, hence cases of missing or lost modules. As for the problems with the modules, teachers mention that the modules are time-consuming, so one contact hour is not enough. There are also some problems with the modules' content including being insufficient, irrelevant, and out-dated.

\footnotetext{
"Perhaps the writing part, it's just too much because the students basically have to write and master five formats of essays; which some are irrelevant and outdated." (M-P-C-R1)

"Actually there are such problems in the module like the purpose of the lesson seems too simple to achieve." (M-P-SL -R5)
}

\section{Significant Problems in Everyday Teaching}

Most of the problems identified by teachers are student-related problems, varying from their poor command of English language to their attitude in English language learning. Some students have low confidence level and some have developed a discouraging attitude to learn English. They also have limited vocabulary and problem in sentence structure, which are very basic skills in language learning. Student variety in a classroom interferes with teachers' lesson planning too. Other than that, teachers identify time constraint, limited resources, and lack of training to be their everyday problems. They also think that module development 
takes time to be mastered and the module content is inadequate for students. In fact, teachers are now burdened with more nonteaching duties that come with the curriculum transformation.

“Most of my students have poor command of English.” (SP-PC -R4)

"As for some group of students, they have developed a discouraging attitude on English, as they do not feel the need to speak in English, as they have grown comfortable with Malay language especially when English is given less emphasis in the country." (SP-SA -R2)

"Too little time with the students; one hour is insufficient." (SP-TA -R5)

"Time is the biggest issue as there is no way that one hour is sufficient for language learning." (SP-TA -R6)

\section{Challenging Aspects in Implementation}

Similarly, the same themes were derived in exploring challenging aspects that teachers face in the implementation process. They are; student attitude, time constraint, limited exposure or lack of training, extra effort from the teachers, and teacher burden. In addition to that, teachers worry about students' progress and the evaluation process conducted only by the teachers.

"It requires a lot of effort from teachers to supplement the curriculum's weaknesses like the illogical number of weekly contact hour, the inexistence of training, and whatnot." (CA-EE -R6)

"Well, the hardest challenge was coping with it actually; it was a sudden change, I was posted the year the transformation took place." (CA-A-R5)

\section{Research Implications}

The research findings have highlighted the problems and challenges that ESL teachers face in the implementation process of the new English language curriculum. It provides in-depth insights on curriculum implementation among teachers in vocational colleges. Fullan (2007) states that the implementation of educational change involves change in practice. Hence, it is only possible to measure change through the investigation of its implementation. It feeds curriculum workers with information on the changes that take place, and whether the changes are expected and desired.

Following are some implications for the stakeholders involved, including ESL teachers, policymakers, training division, and college administrators. As demonstrated by the ESL teachers that are involved in this research, teachers have to remain steadfast in their effort in carrying out their responsibilities as a teacher. It is hoped that these insights on teachers' perseverance in educating their students will inspire fellow ESL teachers to do their best in providing a valuable educational experience for students. As exhibited in the data, teachers become creative when resources are limited, teachers become resourceful when there is lack of training, and teachers form support groups when they are clueless. In short, teachers will always manage to find a solution to every problem, and a way around every obstacle. Such an optimistic stance is required in every teacher, for without teachers, the curriculum blueprint cannot be realised. At the pedagogical level, this research helps teachers to reflect their teaching practices in relation to teaching GE and ESP modules in the new English Language curriculum. Reflective practice is essential for teachers seeking to make positive change and development in their work. In other words, effective teachers need to be thoroughly effective. Kauffman, Mostert, Trent, and Pullen (2006) propose that teachers need to reflect frequently, regularly and vigilantly. It is the only way forward for teachers to evaluate and revise what is taught, how it is taught, and how learning is assessed.

Regarding the aforesaid pressing matter; time allocation, or time constraint, or insufficient contact hour, it is hoped that syllabus designers will realise the dire need to add more contact hours for the English language curriculum to bear results. 'Time' popped up so many times as an answer to so many questions during the interview sessions. Teachers need more time to help students improve, teachers need more time to prepare students for their vocation, and teachers need more time to produce communicative competent beings. One hour limits interaction, and hence hinders language progress. We have to bear in mind of the importance of English language to our future generations to survive in the ever-demanding market. As for the inconsistency of curriculum materials and modules developed at college or state level, it is high time for the policymakers to interfere. Not to say that teachers' autonomy should be revoked altogether, but perhaps better management can be administered. It is possible to select teachers for rounds of module-development process at national level to produce standardised curriculum materials that are course-specific. It is also plausible to create a sub-division that is able to monitor and accredit the materials developed at college-level. In addition to that, college-based ongoing assessments can be included in the monitoring and accreditation process. It is not to make things complicated, but to ensure reliability and validity of the curriculum content and evaluation.

Recommended by teachers, the training division has to start providing proper training to ESL teachers in regard to the new curriculum. Many teachers are not equipped to teach English for Specific Purposes modules. They lack knowledge on the content part that is very much related to students' vocational field. Jargons and terms that are used in a particular field are considered necessary for students' preparation for future vocations, however teachers as laymen in that field, lack the vocabulary. In fact, ESL teachers are only used to teach General English, which is not the same as English for Specific Purposes, English for Vocational Purposes, and even English for Business Purposes. Hence, they need exposure to other types of English too.

Teachers do not complain when they state that their students have poor command in English, for what is there to teach if all the students are masters to English? Teachers acknowledge the fact, so that solutions can be figured out. In the case of vocational colleges in Malaysia, it is believed and proven that college administrators are lenient in enrolling students, even those who do not meet the entry 
requirement. Students who failed their English paper in PMR or PT3 are able to enroll, despite the fact that they do not meet the requirement. It is written in black and white, but they are allowed in by college administrators in their attempt to fulfill the minimum yearly quota in student enrolment. Thus, college administrators should be strict in accepting students, if they want to witness the vocational college's aspiration fulfilled. This research offers a room of evaluation on the demand-supply of related industries. It is important to determine whether the learning outcomes aimed in the new curriculum tally with expected workforce standards among employers. Studies show that there is a demand-supply mismatch in Malaysian industries (Affero Ismail \& Razali Hassan, 2013; Affero Ismail \& Norhasni Zainal Abiddin, 2014; Maizam Alias \& Razali Hassan, 2012; Zuraidah Mohd Zain, 2008). Hence, the findings are able to contribute to the development of curriculum planning and innovation of vocational colleges. Policymakers, including Ministry of Education Malaysia (MOE), TVED, and Malaysian Examination Syndicate will benefit from the insights on the curriculum aims and objectives.

\subsection{CONCLUSION}

It is hoped that this research has shed some light on teachers' perceptions on the new English language curriculum in vocational colleges and its implementation. This research has also unveiled problems and challenges that ESL teachers face in vocational colleges. It is the hope of the researcher that this research will be able to trigger more research on the implementation of English language curriculum in vocational colleges. Views and insights from other stakeholders will be valued, including policymakers, curriculum designers, college administrators, students, parents, as well as the industries' representatives. In fact, observations on teaching practices and learning styles in the classroom are crucial in recording and understanding enacted curriculum in its purest form. This research has drawn a portrayal of teachers' experience in curriculum implementation in the setting of Malaysian vocational colleges. It has outlined and highlighted teachers' experience from three aspects; ESL teachers' perceptions on the new English Language curriculum and its implementation, ESL teachers' strategies in implementing the new English Language curriculum, and the challenges that they face in implementing the new English Language curriculum. In a nutshell, teachers are receptive of the curriculum change and most of them understand the new curriculum well. They have positive feelings towards it despite acknowledging negative curriculum aspects, having curriculum concerns and dealing with problems and challenges. Teachers wish for proper training and support from the higher-ups in order to improve the teaching and learning process. It is vital in ensuring the improvement of students' English language proficiency level.

\section{References}

Affero Ismail \& Norhasni Zainal Abiddin. (2014). Issues And Challenges Of Technical And Vocational Education And Training In Malaysia Towards Human Capital Development. Middle-East Journal of Scientific Research. 19(2), 7-11.

Affero Ismail \& Razali Hassan. (2013, January). Issues and Challenges of Technical and Vocational Education and Training in Malaysia for Knowledge Worker Driven. Paper presented at the National Conference on Engineering Technology 2013 (NCET 2013), Shah Alam, Selangor.

Azmanirah Ab Rahman, Nurfirdawati Muhamad Hanafi, Marina Ibrahim Mukhtar, \& Jamil Ahmad. (2014). Assessment Practices for Competency based Education and Training in Vocational College, Malaysia. Procedia - Social and Behavioral Sciences, 112, 1070-1076. doi: 10.1016/j.sbspro.2014.01.1271

Berg, B. L. (2004). An Introduction to Content Analysis. Qualitative Research Methods for the Social Sciences (5 $5^{\text {th }}$ ed.). Boston: Pearson.

Carless, R. D. (1997). Managing Systematic Curriculum Change: A Critical Analysis Of Hong Kong's Target-Oriented Curriculum Initiatives. International Review of Education, 43(4), 349-366.

Carless, R. D. (1998). A Case Study of Curriculum Implementation in Hong Kong. System, 26(3), 353-368.

Carless, R. D. (1999). Factors Affecting Classroom Implementation: Task-Based Curriculum Renewal in Hong Kong. International Journal of Educational Reform, $8(4), 374-382$.

Creswell, J.W. (2007). Qualitative Inquiry \& Research Design: Choosing Among Five Approaches (2 $2^{\text {nd }}$ ed.). California: SAGE Publications, Inc.

Dudley-Evans, T. \& St. John, M. J. (1998). Developments in English for Specific Purposes: A Multi-Disciplinary Approach. Cambridge: Cambridge University Press.

Fullan, M. (2007). The New Meaning of Educational Change (4th ed.). New York: Teachers College Press.

Fullan, M., \& Miles, M. (1992). Getting Reforms Right: What Works And What Doesn't. Phi Delta Kappan, 73(10), 745-752.

Hancock, B., Windridge, K., \& Ockleford, E. (2009). An Introduction To Qualitative Research. United Kingdom: The NIHR Research Design Service for the East Midlands/Yorkshire \& the Humber.

Harvey, T.R. (1990). Checklist for Change: A Pragmatic Approach To Creating And Controlling Change. Massachusetts: Allyn and Bacon, Inc.

Hiew, W. (2012). English Language Teaching and Learning Issues in Malaysia: Learners' Perceptions Via Facebook Dialogue Journal. Journal of Arts, Science \& Commerce, 3(1), 356-366.

Kauffman, J. M., Mostert, M. P., Trent, S. C., \& Pullen, P. L. (2006). Managing Classroom Behavior: A Reflective Case-Based Approach (4 ${ }^{\text {th }}$ ed.). New Jersey: Pearson. Kirkpatrick, R., \& Zang, Y. (2011). The Negative Influences of Exam-Oriented Education on Chinese High School Studies: Backwash From Classroom To Child. Language Testing in Asia, 1(3), 36-45.

Kyriakides, L. (1997). Influences on Primary Teacher's Practice: Some Problems For Curriculum Change Theory. British Educational Research Journal, $23(1)$, $39-46$. Li, D. (1998). "It's Always More Difficult Than You Plan And Imagine": Teachers' Perceived Difficulties In Introducing The Communicative Approach in South Korea. TESOL Quarterly, 32(4), 677-703.

Maizam Alias \& Razali Hassan. (2012, December). TVET Agency-Industry Collaborations: Addressing Diversity. Paper Presented at the Proceedings of the 2nd UPI International Conference on Technical and Vocational Education and Training, Bandung, Indonesia.

Moustakas, C. (1994). Phenomenological Research Methods. United States of America: SAGE Publications, Inc.

Mulat, L. (2003). Teachers' Attitudes towards Communicative Language Teaching and Practical Problems in its Implementation. (Master dissertation, University of Addis Ababa, Ethiopia, Africa.) Retrieved from http://citeseerx.ist.psu.edu/viewdoc/download?doi=10.1.1.539.8107\&rep=rep1\&type=pdf

Noorazman Abd Samad, Hairuddin Harun, Wan Mohd Rashid Wan Ahmad, Noor Hisham Jalani, \& Jamil Abd Baser. (2013, October). The Readiness of Vocational Colleges in Malaysia to Implement Aprenticeship Programmed in Collaboration with Industry. Paper presented at the Malaysia International Technical HRD $\&$ 9th ASIAN Academic Society for Vocational Education and Training Conference 2013, Kuching, Sarawak.

Nunan, D. (2011). The 7 Myths of Language Learning. Retrieved February 6, 2013 from http://static.globalenglish.com/files/reports/GlobEng_Whitepap_Nunan_EN_US_FINAL.pdf?q=files

O'Sullivan, M. C. (2002). Reform Implementation and the Realities within which Teachers Work: A Namibian Case Study. Compare, 32(2), 219-237.

Ornstein A. C., \& Hunkins F. P. (2009). Curriculum; Foundations, Principles, And Issues ( $5^{\text {th }}$ ed.). United States of America: Pearson.

Phani Kiran. (2013). Challenges to an ESP Teacher. The Journal for ESL Teachers and Learners, 2, 200-205.

Scharle, A., \& Szabó, A. (2000). Learner Autonomy: A Guide To Developing Learner Responsibility. United Kingdom: Cambridge University Press.

Schramm-Possinger, M. (2012). Student Teacher Beliefs Before and After the Internship (Doctoral dissertation, Rutgers University-Graduate School-New Brunswick, New Jersey.) Retrieved from https://rucore.libraries.rutgers.edu/rutgers-lib/37473/pdf/1/ 
Sirhajwan, I, Lee, L. F., Sidhu, G. K., \& Teoh, S. H. (2014). The Use of Consciousness-raising Tasks in Promoting the Correct Use of the Verb "Be" among Students in Vocational Colleges. Theory and Practice in Language Studies, 4(9), 1792-1803.

Smith, J., Flower, P. \& Larkin, M. (2009). Interpretative Phenomenological Analysis: Theory, method and research. London: Sage.

Strauss, A. L., \& Corbin, J. M. (1998). Basics of Qualitative Research (2 ${ }^{\text {nd }}$ ed.). California: Sage.

Taba, H., \& Spalding, W. B. (1962). Curriculum Development: Theory and practice. New York: Harcourt, Brace \& World.

Thompson, D., Bell, T., Andreae, P., \& Robins, A. (2013). The Role of Teachers in Implementing Curriculum Changes. Proceeding of the 44th ACM technical symposium on Computer science education (SIGCSE '13), 245-250. doi:10.1145/2445196.2445272

Wang, H. (2008). Language Policy Implementation: A Look At Teachers' Perceptions. Asian EFL Journal, 30(1), 1-25.

Wang, H., \& Han, H. (2002). The Development of College English Curriculum in China. Carleton Papers in Applied Language Studies, 16(17), 75-97.

Webb, R. (2010). The Impact of Educational Reform on Primary School Teachers: The English Experience. Primary Children Educational Research Journal, 5, 17-38.

Zuraidah Mohd Zain. (2008). TVET in Malaysia. Universiti Malaysia Perlis. 